\title{
SISTEM PAKAR CERTAINTY FACTOR DALAM MENDIAGNOSIS INDIKASI PENYAKIT KATARAK PADA ANAK
}

\author{
Randy Permana'), Rini Sovia ${ }^{2)}$, Muhammad Reza ${ }^{3)}$, dan Hanippa Prima Putra ${ }^{4)}$ \\ ${ }^{1234}$ Teknik Informatika, Universitas Putra Indonesia YPTK Padang \\ J1. Raya Lubuk Begalung, Kota Padang, Sumatera Barat, 25221 \\ E-mail: randy_permana@upiyptk.ac.id ${ }^{1)}$,rini_sovia@upiyptk.ac.id²), Muhammad_Reza@upiyptk.ac.id ${ }^{3)}$, \\ hanifprimaputra@gmail.com ${ }^{4}$
}

\begin{abstract}
ABSTRAK
Sistem pakar merupakan salah satu bagian dari cabang ilmu kecerdasan buatan yang mengombinasikan pengalaman dan mesin inferensi untuk mendapatkan suatu pengetahuan. Dengan membangun sistem pakar, pengguna bisa mendapatkan pengetahuan yang bersumber dari sistem sama seperti bertemu dengan seorang pakar yang sebenarnya. Terdapat banyak kasus yang dapat dipecahkan oleh sistem pakar antara lain : kesehatan, pertanian, peternakan, otomotif, eletronik dan masih banyak lagi yang lainnya. Pada penelitian ini sistem pakar menerapkan metode certainty factor atau yang disebut dengan faktor kepastian, merupakan metode berbentuk metrik untuk membuktikan apakah suatu fakta yang diberikan pengguna pasti atau tidak dengan yang terdapat di dalam sistem pakar. Kasus yang akan dipecahkan oleh sistem pakar ini adalah pendeteksian secara dini terhadap penyakit katarak yang rentan menyerang bayi maupun anak di bawah umur. Penyakit katarak pada anak umumnya disebabkan oleh beberapa hal seperti kelahiran bayi secara prematur, Ibu yang mengandung mengidap rubella atau toksoplasma, dan juga termasuk makanan yang dikonsumsi oleh ibu yang sedang mengandung. Hasil dari Sistem pakar ini akan menyimpulkan apakah seorang anak menderita penyakit katarak Congenital, Juvenile, Traumatic ataupun tidak sama sekali berdasarkan gejala yang dipilih oleh seorang pengguna berdasarkan nilai keyakinan yang dimiliki oleh seorang pengguna.
\end{abstract}

Kata Kunci : Certainty Factor, Kecerdasan Buatan, Katarak, Sistem Pakar

\section{PENDAHULUAN}

Mata merupakan salah satu pengindraan dari lima panca indra yang dimiliki oleh seorang manusia. Katarak merupakan penyakit pada mata manusia, biasanya penyakit ini rentan terjadi pada manusia usia lanjut (manula). Semakin bertambahnya umur manusia, maka protein yang membentuk lensa mata akan menjadi berubah, sehingga menyebabkan berkurangnya kualitas kandungan air yang terdapat di lensa mata. Lensa mata lama kelamaan akan berubah menjadi buram dan menyebabkan berkurangnya kemampuan visibilitas seseorang. Seiring dengan berjalannya waktu, katarak tidak lagi diderita pada usia lanjut saja, namun katarak mulai banyak diderita oleh anak dan juga tidak tertutup kemungkinan juga diderita oleh bayi. Menurut (Irawan, Saerang and Tongku, 2015), Penyakit Katarak merupakan penyakit yang berkaitan dengan gangguan penglihatan terbanyak diderita di seluruh penjuru dunia. Estimasi peningkatan penderita penyakit katarak yang saat ini sudah mencapai 17 Juta orang, diperkirakan pada tahun 2020 akan mencapai jumlah 40 juta orang lebih. Sementara itu untuk wilayah Amerika Serikat katarak terjadi pada orang dengan rata - rata usia 65 sampai 75 tahun dengan prevalensi peningkatan dimulai $10 \%$ mencapai $50 \%$ dan $70 \%$ peningkatan terjadi untuk mereka yang berusia senja (75 tahun ke atas) .

Terdapat beberapa jenis penyakit katarak berdasarkan penyebab seperti (Reisa, 2014) katarak kongenital merupakan katarak yang muncul pada usia dini (bayi di bawah satu tahun) yang disebabkan oleh bawaan semenjak dilahirkan, katarak Juvenile merupakan peningkatan dari katarak kongenital yang terlihat pada usia di atas satu tahun dan mencapai di bawah lima puluh tahun dan katarak Traumatik : merupakan katarak yang disebabkan oleh cedera yang terjadi dimata seperti trauma perforasi (luka tusuk atau tembakan) ataupun disebabkan oleh benda tumpul yang dapat terlihat beberapa hari ataupun beberapa tahu setelah cedera terjadi.

Sistem pakar dapat diartikan sebagai sebuah sistem yang didesain untuk menduplikasi kemampuan seorang pakar di dalam melakukan pemecahan permasalahan berdasarkan input pernyataan yang diberikan ke dalam sistem tersebut (Vlahavas, 2008) (Anwar $d k k . ., 2016$ ). Sistem bekerja dengan cara menerima dialog dari pengguna, menjawab pertanyaan dan menyelesaikan permasalahan seperti layaknya dilakukan oleh tenaga yang memiliki kemampuan di dalam bidang tersebut (Vlahavas, 2008) (Anwar $d k k . .$, 2016. Jaminan tingkat kesuksesan penelusuran dari suatu sistem pakar sangat tergantung kepada kemampuan sistem pakar dalam menjelaskan solusi atas respons atau tanggapan yang dicapai (Vlahavas, 2008) (Anwar $d k k . ., 2016$ ).

Berikut merupakan kelebihan yang didapatkan dari menggunakan sistem pakar, diantaranya meningkatkan produktivitas, Sistem pakar mampu membuat orang awam bekerja seperti seolah - olah adalah pakar yang sebenarnya, meningkatkan kualitas dimana solusi yang 
diberikan selalu konsisten, Memindahkan kemampuan dan pengetahuan seorang pakar, dapat beroperasi dilingkungan yang berbahaya, Memudahkan akses pengetahuan seorang pakar, meningkatkan peran dari penerapan sistem komputer, bisa bertindak sebagai media untuk pendukung di dalam proses pelatihan, Penyelesaian atau solusi yang diberikan oleh sistem pakar akan lebih baik dikarenakan mengumpulkan pengetahuan dari berbagai pakar (Sutojo, mulyanto and suhartono, 2011).

Metode Certainty Factor sangat sesuai untuk digunakan pada sistem pakar yang digunakan untuk mendiagnosis sesuatu yang belum pasti, hal ini dikarenakan metode yang terdapat pada Certainty Factormelakukan pembukti sebuah fakta dengan melihat nilai kepastian terhadap fakta tersebut (Giarratano, J. C. dan Riley, 2005) (Wulandari, 2014). Certainty Factor diharapkan dapat mendeteksi penyakit yang diderita berdasarkan gejala - gejala yang dirasakan pasien dan memberikan solusi untuk menangani penyakit yang diderita oleh seorang pasien (Atmojo and Utami, 2017).

Teori Certainty Factor (CF) diusulkan oleh Shortliffe dan Buchanan pada tahun 1975 untuk mengkombinasi ketidakpastian pemikiran (inexact reasoning) seorang pakar (Mevung $d k k . ., 2017)$. Dengan menggunakan teori ini, maka ketidakpastian dalam pengambilan keputusan berdasarkan gejala-gejala yang dirasakan atau diinputkan oleh user dapat di atasi dengan baik (Setyaputri and Fadlil, 2018).

Certainty Factor menggunakan dua faktor kepastian yang bersumber dari pakar dalam bentuk aturan (rule) dan faktor kepastian yang di-input-kan oleh user berdasarkan aturan yang telah ditentukan sebelumnya oleh seorang pakar(Kusrini, 2006). Pada sisi seorang pakar, faktor kepastian merupakan keyakinan seorang pakar terhadap hubungan antecedent dan konsekuensi. Sementara itu pada sisi pengguna, faktor keyakinan menunjukkan seberapa yakin terhadap antecedent di dalam sistem pakar (Kusrini, 2006). Keyakinan di dalam Certainty Factor merupakan hipotesisfaktual yang dinilai oleh seorang pakar yang memiliki kompetensi dibidangnya (Agus, Wulandari and Astuti, 2018).

Katarak pada anak dapat terjadi sejak lahir atau terlihat segera setelah lahir yang disebut dengan katarak kongenital, katarak yang terjadi pada tahun pertama disebut katarak infantil, sedangkan yang berkembang selama 12 tahun pertama disebut dengan katarak juvenil (Wahyumi, Amra and others, no date).

Salah satu penelitian terdahulu dengan membahas metode yang sama yaitu sistem pakar dengan metode CertaintyFactoryang digunakan sebagai media untuk mendiagnosis penyakit THT pada manusia (Sutojo, mulyanto and suhartono, 2011), Selain itu Certainty Factor yang diteliti oleh (Mitra, Sovia and Permana, 2019) digunakan sebagai sistem untuk mendeteksi penyakit Kulit pada kucing jenis Persia dimana beberapa jenis penyakit yang memiliki kesamaan gejala dapat diidentifikasi dengan baik melalui sistem pakar ini
(Mevung dkk.., 2017) melakukan penelitian dengan menggunakan Certainty Factor sebagai sistem untuk mendeteksi gangguan kejiwaan seperti skizofrenia, bipolar, depresi dan anxiety disorder. Sementara itu Certainty Factor juga dapat diaplikasikan untuk mendiagnosis penyakit yang terdapat pada tanaman seperti yang dilakukan oleh (Arifin, Slamin and Retnani, 2017), dimana Certainty factor dimanfaatkan untuk mengetahui penyakit dan gangguan hama yang terdapat pada tanaman tembakau.

\section{RUANG LINGKUP}

Terdapat beberapa cakupan di dalam penelitian seperti yang dijabarkan di bawah ini.

\subsection{Cakupan Permasalahan}

1. Bagaimana mengetahui gejala awal terjadinya katarak pada anak?

2. Bagaimana cara penanggulangan katarak pada anak dan dampak buruk terhadap organ lainnya?

3. Bagaimana cara pencarian solusi terhadap penderita katarak dan masyarakat?

\subsection{Batasan Penelitian}

Dalam penelitian ini penulis perlu memberikan batasan masalah yang membahas tentang katarak pada anak yaitu katarak Kongenital, Juvenil dan Traumatik dengan metode certainty factor, mulai dari mengetahui gejala awal, penanganannya, pengobatannya.

\subsection{Rencana Hasil Penelitian}

Berdasarkan cakupan permasalahan di atas dapat ditarik beberapa rencana dari penelitian:

1. Dengan mengetahui gejala awal penyakit katarak pada anak, diharapkan masyarakat lebih peduli terhadap kesehatan mata, terutama pada orang tua anak terhadap kesehatan mata anaknya.

2. Dengan mengetahui gejala awal tersebut, diharapkan penderita katarak Congenital, Juvenile dan Traumatik mendapatkan penanganan serius serta penanggulangannya.

3. Dengan adanya pencarian solusi diharapkan mampu memberikan dampak positif bagi penderita katarak dan masyarakat banyak.

\section{BAHAN DAN METODE}

Dua faktor terpenting dari sebuah sistem pakar terletak pada pemilihan data yang sesuai untuk kebutuhan analis sistem pakar dan juga metode yang sesuai dengan kasus yang akan diselesaikan oleh sistem tersebut.

\subsection{Persiapan Data.}

Data yang digunakan dalam penelitian ini bersumber dari seorang pakar yang memiliki profesi sebagai dokter penyakit mata pada salah satu rumah sakit swasta di Kota Padang yaitu dr. Naima Lassie, S.pM. Berikut 
merupakan jenis dan gejala penyakit katarak yang diperoleh dari pakar tersebut.

1. Data Jenis-jenis Penyakit Katarak Pada Anak

Penyakit katarak dapat dibedakan menjadi beberapa bagian berdasarkan kejadiannya, antara lain: katarak yang merupakan pembawaan semenjak lahir (kongenital), katarak yang terbentuk di usia dini (Juvenil), dan katarak yang terbentuk karena terjadinya trauma di mata atau disebut (Taumatik). Berikut merupakan penjelasan dari masing-masing penyakit Katarak.

Tabel 1. Jenis-Jenis Penyakit Katarak Pada Anak

\begin{tabular}{|c|c|l|}
\hline $\begin{array}{c}\text { Kode } \\
\text { penyakit }\end{array}$ & \multicolumn{1}{|c|}{$\begin{array}{c}\text { Nama } \\
\text { penyakit }\end{array}$} & \multicolumn{1}{c|}{ Keterangan } \\
\hline P001 & Kongenital & $\begin{array}{l}\text { Merupakan masalah mata menjadi } \\
\text { keruh yang terjadi sejak lahir, } \\
\text { lensa mata berperan untuk } \\
\text { memfokuskan cahaya yang masuk } \\
\text { ke dalam mata menuju retina, } \\
\text { sehingga dengan begitu mata } \\
\text { dapat menangkap gambar dengan } \\
\text { jelas. Namun pada seseorang yang } \\
\text { menderita katarak, sinar yang } \\
\text { masuk ke matanya akan tersebar } \\
\text { pada saat melewati lensa mata } \\
\text { yang keruh dan menyebabkan } \\
\text { gambar yang diterima mata tidak } \\
\text { jelas atau kabur dan terdistorsi. }\end{array}$ \\
\hline P002 & Juvenil & $\begin{array}{l}\text { Merupakan katarak lembek yang } \\
\text { terdapat pada manusia, pada usia } \\
\text { muda dan mulai terbentuknya } \\
\text { pada usia tiga bulan sampai } \\
\text { sembilan tahun. }\end{array}$ \\
\hline P003 & Traumatik & $\begin{array}{l}\text { Merupakan katarak yang muncul } \\
\text { sebagai akibat cedera pada mata } \\
\text { yang dapat diakibatkan benturan } \\
\text { benda tumpul ataupun trauma } \\
\text { perforasi yang terlihat sesudah } \\
\text { beberapa hari ataupun beberapa } \\
\text { tahun. }\end{array}$ \\
\hline
\end{tabular}

2. Data Gejala Penyakit Katarak

Penyakit Katarak memiliki beberapa gejala fisik yang dapat dirasakan oleh seorang penderita, namun tidak semua gejala akan dirasakan oleh seorang penderita.

Pada Tabel 2. gejala - gejala tersebut dikelompokkan berdasarkan jenis penyakitnya dan diberikan kode gejala untuk mengidentifikasi setiap gejala yang terdapat pada penyakit katarak.

Tabel 2. Data Gejala-Gejala Penyakit Katarak

\begin{tabular}{|c|c|c|}
\hline $\begin{array}{c}\text { Kode } \\
\text { gejala }\end{array}$ & Nama Gejala & Jenis Penyakit \\
\hline G001 & Keturunan atau Genetik & Kongenital \\
\cline { 1 - 2 } G002 & $\begin{array}{c}\text { Infeksi selama kehamilan } \\
\text { (rubella, simplex virus herpes, } \\
\text { omegalovirus, cacar, dan } \\
\text { toksoplasmosis) }\end{array}$ & \\
\hline G003 & Reaksi obat & \\
\hline G004 & Trauma mata & \\
\hline
\end{tabular}

\begin{tabular}{|c|c|c|}
\hline G005 & Diabetes & \\
\hline G006 & $\begin{array}{l}\text { Toxocariasis (infeksi parasit } \\
\text { yang menginfeksi mata) }\end{array}$ & \\
\hline G007 & $\begin{array}{c}\text { Galatosemia (kekurangan } \\
\text { enzim) }\end{array}$ & \\
\hline G008 & Berawan dilensa & \\
\hline G009 & $\begin{array}{l}\text { Gerakan mata yang tidak biasa } \\
\text { (Nytagmus) }\end{array}$ & \\
\hline G010 & $\begin{array}{c}\text { Bola mata bergoyang-goyang } \\
\text { atau juling }\end{array}$ & \\
\hline G011 & Pandangan kabur & \multirow[t]{5}{*}{ Juvenil } \\
\hline G012 & Silau & \\
\hline G013 & Perubahan daya lihat warna & \\
\hline G014 & $\begin{array}{c}\text { Penurunan ketajaman } \\
\text { penglihatan }\end{array}$ & \\
\hline G015 & $\begin{array}{c}\text { Diplopia monocular } \\
\text { (penglihatan ganda pada satu } \\
\text { mata) }\end{array}$ & \\
\hline G016 & $\begin{array}{l}\text { Luka memar area mata (benda } \\
\text { tumpul) }\end{array}$ & \multirow{5}{*}{ Traumatik } \\
\hline G017 & Luka perforasi (benda tajam) & \\
\hline G018 & Radiasi sinar & \\
\hline G019 & Zat kimia & \\
\hline G020 & Sensivitas kontras & \\
\hline
\end{tabular}

\subsection{Metode analisis Certainty Factor}

Certainty Factor menggunakan beberapa ungkapan seperti: mungkin, kemungkinan besar, hampir pasti untuk mengakomodasi tingkat keyakinan seorang pakar di dalam melakukan analisa terhadap suatu permasalahan (Setyaputri and Fadlil, 2018).

Formulasi Certainty Factor pada (1) (2).

$$
\begin{aligned}
& C F(\text { Rule })=M B(H, E)-M D(H, E) \\
& M B(H, E)=\{(\max [P(H \mid E), P(H)]-P(H)) /(\max [1, \\
& 0]-P(H))
\end{aligned}
$$

$M D(H, E)=\{(\min [P(H \mid E), P(H)]-P(H)) /(\min [1$, $0]-P(H))$

Dimana (1) (2).

$\mathrm{CF}($ Rule $)=$ faktor kepastian

$\mathrm{MB}(\mathrm{H}, \mathrm{E})=$ measure of belife (ukuran kepercayaan) terhadap hipotesis $\mathrm{H}$, jika diberikan evidence $\mathrm{E}$ (antara o dan 1).

$\mathrm{MD}(\mathrm{H}, \mathrm{E})=$ measure of disbelife (ukuran ketidakpastian) terhadap evidence $\mathrm{H}$, jika diberikan evidence $\mathrm{E}$ (antara 0 dan 1).

$\mathrm{P}(\mathrm{H})=$ probabilitas kebenaran hipotesis $\mathrm{H}$

$\mathrm{P}(\mathrm{H} \mid \mathrm{E})=$ probabilitas bahwa $\mathrm{H}$ benar karena fakta $\mathrm{E}$

\section{PEMBAHASAN}

Analisis certainty factor Merupakan proses perhitungan, dimana dapat dilihat sebagai berikut : 


\subsection{Rule - Rule Sistem Pakar Penyakit Katarak.}

Rule sebuah teknik representasi pengetahuan sintak rule IF E (Evidence yang ada) Then $\mathrm{H}$ (Hipotesa atau kesimpulan yang dihasilkan).

R1 = IF Keturunan atau genetik AND Infeksi selama kehamilan AND Reaksi obat AND Trauma mata THEN Penyakit $=$ Katarak Kongenital $(\mathbf{C F}=\mathbf{0 . 8 0})$

R2 = IF Galatosemia AND Gerakan mata yang tidak biasa AND Bola mata bergoyang-goyang atau juling AND Toxocariasis THEN Penyakit $=$ Katarak Kongenital $(\mathbf{C F}=\mathbf{0 . 7 5})$

R3 = IF Keturunan atau genetik AND Diabetes AND Reaksi obat AND Berawan di lensa THEN Penyakit = Katarak Kongenital $(\mathbf{C F}=\mathbf{0 . 8 0})$

R4 = IF Pandangan kabur AND Silau AND Perubahan daya lihat warna THEN Penyakit $=$ Katarak Juvenil $(\mathbf{C F}=\mathbf{0 . 8 0})$

R5 = IF Penurunan ketajaman penglihatan AND Diplopia monokular AND Silau THEN Penyakit = Katarak Juvenil $(\mathbf{C F}=\mathbf{0 . 6 5})$

R6 = IF Luka memar area mata (benda tumpul) AND Luka perforasi (benda tajam) AND Radiasi sinar AND Zat kimia THEN Penyakit $=$ Katark Traumatik $(\mathbf{C F}=$ 0.80)

R7 = IF Luka perforasi (benda tajam) AND Sensivitas kontras AND Penurunan ketajaman penglihatan AND Silau THEN Penyakit $=$ Katarak Traumatik $(\mathbf{C F}=\mathbf{0 . 6 5})$

R8 = IF Radiasi sinar AND Luka memar area mata (benda tumpul) AND Zat kimia AND Silau THEN penyakit $=$ Katarak Traumatik $(\mathbf{C F}=\mathbf{0 . 7 0})$

Simulasi Dialog user dengan sistem Pakar merupakan dialog antara user dengan sistem pakar untuk mengetahui keluhan yang sedang dialami oleh penderita atau orang tua anak.

SP:"Apakah keturunan anda ada mengalami penyakit yang sama (katarak) (Nilai kepastian [0-1])"'?

User :"Ya, CF $=(0.4)^{66}$

SP :"Apakah anda mengalami infeksi selama kehamilan (Nilai kepastian [0-1]'?

User :"Ya, CF $=(0.8)^{\text {“ }}$

SP :"Apakah anak anda pernah mengalami reaksi obat (Nilai kepastian [0-1]) "?

User :"Ya, $\mathrm{CF}=(0.4)$ “

SP :"Apakah anak anda pernah mengalami trauma pada mata (Nilai kepastian [0-1]) "?

User :"Tidak “"

SP :"Apakah anda mengalami penyakit diabetes (Nilai kepastian [0-1]) “?
User :"Ya, $\mathrm{CF}=(0.8)$ “

SP :"Apakah anak anda mengalami Toxocariasis (infeksi parasit mata) (Nilai kepastian [0-1]) "?

User :"YA, CF = (0.4) “

SP :"Apakah anak anda mengalami Galatosemia (kekurangan enzim) (Nilai kepastian [0-1]) “?

User :"Ya, CF = (0.4) “

SP :"Apakah mata anak anda mengalami berawan dilensa (Nilai kepastian [0-1]) “?

User :"Ya, $\mathrm{CF}=(0.8)$ “

SP :"Apakah anak anda mengalami Nygtamus (gerakan mata yang tidak biasa) (Nilai kepastian [0-1]) "?

User :"Ya, CF = (0.4) "

SP :"Apakah bola mata anak anda bergoyang-goyang atau juling bila dibuka (Nilai kepastian [0-1]) "?

User :"Ya, CF $=(0.4)^{6 /}$

SP :"Apakah anak anda mengalami pandangan kabur (Nilai kepastian [0-1]) "?

User :"Ya, CF $=(0.8)^{66}$

SP :"Apakah anak anda mengalami silau (Nilai kepastian [0-1]) “?

User :"Ya, CF = (0.8) “"

SP :"Apakah anak anda mengalami perubahan daya lihat jika melihat warna (Nilai kepastian [0-1]) "?

User :"Ya, $\mathrm{CF}=(0.6)^{\text {“ }}$

SP :"Apakah anak anda mengalami penurunan ketajaman penglihatan (Nilai kepastian [0-1]) "'?

User :'Ya, CF $=(0.4)$ “"

SP :"Apakah anak anda mengalami diplopia monocular (penglihatan ganda pada satu mata) (Nilai kepastian [0-1]) "?

User :'Ya, CF = (0.6) “

SP :"Apakah anak anda pernah luka memar terkena benda tumpul pada area mata (Nilai kepastian [0-1]) “?

User :"Ya, CF = (0.8)“"

SP :"Apakah anak anda pernah mengalami luka perforasi atau terkena benda tajam pada area mata (Nilai kepastian [0-1]) "?

User :"Tidak “"

SP :"Apakah anak anda pernah terkena radiasi sinar (Nilai kepastian [0-1]) "?

User :"Ya CF $=(0.4)^{\text {“" }}$

SP :"Apakah anak anda pernah terkena zat kimia pada area mata (Nilai kepastian [0-1]) "?

User :'Y $\quad$ a, $\mathrm{CF}=(0.4)$ “

SP :"Apakah anak anda mengalami sensivitas kontras saat menonton televisi atau laptop (Nilai kepastian [0$1])^{\text {‘? }}$ ?

User :'Y $\quad$ a, $\mathrm{CF}=(0.4)^{“ 6}$.

\subsection{Proses Rule Dari Penyakit}

Proses rule mengacu pada pohon keputusan yang akan dibuat, berikut terdapat beberapa rule untuk pengetahuan mengenai gangguan dan masalah yang terjadi pada penyakit katarak pada anak, proses rule tersebut dapat dilihat pada tabel 3. 
Tabel 3. Proses Rule Dari Penyakit

\begin{tabular}{|c|c|}
\hline Rule & Keterangan \\
\hline Rule 1 & $\begin{array}{l}\text { IF G001 }(\mathrm{CF}=0.4) \text { AND G002 }(\mathrm{CF}=0.8) \text { AND } \\
\text { G003 }(\mathrm{CF}=0.4) \text { AND G004 THEN P01 }(\mathrm{CF}= \\
0.80)\end{array}$ \\
\hline Rule 2 & $\begin{array}{l}\text { IF G007 }(\mathrm{CF}=0.4) \text { AND G009 }(\mathrm{CF}=0.4) \text { AND } \\
\text { G010 }(\mathrm{CF}=0.4) \text { AND G006 }(\mathrm{CF}=0.4) \text { THEN } \\
\text { P01 }(\mathrm{CF}=0.75)\end{array}$ \\
\hline Rule 3 & $\begin{array}{l}\text { IF G001 }(\mathrm{CF}=0.4) \text { AND G005 }(\mathrm{CF}=0.8) \text { AND } \\
\text { G003 }(\mathrm{CF}=0.4) \text { AND G008 }(\mathrm{CF}=0.8) \text { THEN } \\
\text { P01 }(\mathrm{CF}=0.80)\end{array}$ \\
\hline Rule 4 & $\begin{array}{l}\text { IF G011 }(\mathrm{CF}=0.8) \text { AND G012 }(\mathrm{CF}=0.8) \text { AND } \\
\mathrm{G} 013(\mathrm{CF}=0.6) \text { THEN P02 }(\mathrm{CF}=0.80)\end{array}$ \\
\hline Rule 5 & $\begin{array}{l}\text { IF G014 (CF=0.4) AND G015 (CF=0.6) AND } \\
\text { G012 (CF=0.8) THEN P02 (CF= } 0.65)\end{array}$ \\
\hline Rule 6 & $\begin{array}{l}\text { IF G016 }(\mathrm{CF}=0.8) \text { AND G017 AND G018 } \\
(\mathrm{CF}=0.4) \text { AND } \mathrm{G} 019(\mathrm{CF}=0.4) \\
(\mathrm{CF}=0.80)\end{array}$ \\
\hline Rule 7 & $\begin{array}{l}\text { IF G017 AND G020 }(\mathrm{CF}=0.4) \text { AND G014 } \\
(\mathrm{CF}=0.8) \text { AND G012 }(\mathrm{CF}=0.8) \text { THEN P03 } \\
(\mathrm{CF}=0.65)\end{array}$ \\
\hline Rule 8 & $\begin{array}{l}\text { IF G018 (CF=0.4) AND G016 (CF=0.8) AND } \\
\text { G019 }(\mathrm{CF}=0.4) \text { AND G012 }(\mathrm{CF}=0.8) \text { THEN } \\
\text { P03 }(\mathrm{CF}=0.70)\end{array}$ \\
\hline
\end{tabular}

Dari rule pada tabel 3. berdasarkan hasil diskusi sistem terhadap penderita maka didapatkan fakta baru dari setiap gejala seperti rangkuman dari tabel 4 .

Tabel 4. Fakta Baru

\begin{tabular}{|c|c|}
\hline Gejala & $\mathrm{CF}$ \\
\hline Keturunan atau Genetik & $\begin{array}{c}\text { Evidence } \\
\mathrm{CF}=0.4\end{array}$ \\
\hline $\begin{array}{l}\text { Infeksi selama kehamilan (rubella, simplex } \\
\text { virus herpes, cytomegalovirus, cacar, dan } \\
\text { toksoplasmosis) }\end{array}$ & $\begin{array}{l}\text { Evidence } \\
\mathrm{CF}=0.8\end{array}$ \\
\hline Reaksi obat & $\begin{array}{r}\text { Evidence } \\
\mathrm{CF}=0.4\end{array}$ \\
\hline \multicolumn{2}{|l|}{ Trauma mata } \\
\hline Diabetes & $\begin{array}{l}\text { Evidence } \\
\mathrm{CF}=0.8\end{array}$ \\
\hline $\begin{array}{l}\text { Toxocariasis (infeksi parasit yang } \\
\text { menginfeksi mata) }\end{array}$ & $\begin{array}{l}\text { Evidence } \\
\mathrm{CF}=0.4\end{array}$ \\
\hline Galatosemia (kekurangan enzim) & $\begin{array}{r}\text { Evidence } \\
\mathrm{CF}=0.4 \\
\end{array}$ \\
\hline Berawan di lensa & $\begin{array}{l}\text { Evidence } \\
\text { CF }=0.8\end{array}$ \\
\hline Gerakan mata yang tidak biasa (Nytagmus) & $\begin{array}{r}\text { Evidence } \\
\text { CF }=0.4\end{array}$ \\
\hline Bola mata bergoyang-goyang atau juling & $\begin{array}{l}\text { Evidence } \\
\mathrm{CF}=0.4\end{array}$ \\
\hline Pandangan kabur & $\begin{array}{l}\text { Evidence } \\
\mathrm{CF}=0.8\end{array}$ \\
\hline Silau & $\begin{array}{l}\text { Evidence } \\
\mathrm{CF}=0.8\end{array}$ \\
\hline Perubahan daya lihat warna & $\begin{array}{l}\text { Evidence } \\
\text { CF }=0.6\end{array}$ \\
\hline Penurunan ketajaman penglihatan & $\begin{array}{l}\text { Evidence } \\
\mathrm{CF}=0.4 \\
\end{array}$ \\
\hline $\begin{array}{l}\text { Diplopia monocular (penglihatan ganda } \\
\text { pada satu mata) }\end{array}$ & $\begin{array}{l}\text { Evidence } \\
\mathrm{CF}=0.6\end{array}$ \\
\hline Luka memar area mata (benda tumpul) & Evidence \\
\hline
\end{tabular}

\begin{tabular}{|l|c|}
\hline & $\mathbf{C F}=\mathbf{0 . 8}$ \\
\hline Luka perforasi (benda tajam) & \\
\hline Radiasi sinar & Evidence \\
& $\mathbf{C F}=\mathbf{0 . 4}$ \\
\hline Zat kimia & Evidence \\
& $\mathbf{C F}=\mathbf{0 . 4}$ \\
\hline Sensivitas kontras & Evidence \\
& $\mathbf{C F}=\mathbf{0 . 4}$ \\
\hline
\end{tabular}

Langkah berikutnya dilakukan perhitungan terhadap nilai eviden yang didapatkan dari user tersebut.

R1 = Tidak dieksekusi karena eviden TIDAK

R2 = IF Galatosemia AND Gerakan mata yang tidak biasa AND Bola mata bergoyang-goyang atau juling AND Toxocariasis THEN Penyakit $=$ Katarak Kongenital $(\mathrm{CF}=0,75)$.

CF 2 = (Galatosemia, Gerakan mata yang tidak biasa, Bola mata bergoyang-goyang atau juling, Toxocariasis)

$$
\begin{aligned}
& =\operatorname{MIN}(0,4 ; 0,4 ; 0,4 ; 0,4) * 0,75 \\
& =0,4 * 0,75 \\
& =0,3
\end{aligned}
$$

Fakta baru : Penyakit Katarak Kongenital dengan nilai hipotes $a=0,3$

R3 = IF Keturunan atau genetik AND Diabetes AND Reaksi obat AND Berawan di lensa THEN Penyakit = Katarak Kongenital $(\mathrm{CF}=0,80)$

CF 3 =(Keturunan atau genetik, Diabetes, Reaksi obat, Berawan di lensa)

$$
\begin{aligned}
& =\operatorname{MIN}(0,4 ; 0,8 ; 0,4 ; 0,8) * 0,80 \\
& =0,4 * 0,80 \\
& =0,32
\end{aligned}
$$

Fakta baru : Penyakit katarak kongenital dengan nilai hipotesa $=0,32$

R4 = IF Pandangan kabur AND Silau AND Perubahan daya lihat warna THEN Penyakit $=$ Katarak Juvenil $(\mathrm{CF}$ $=0,80$ )

CF 4 = (Pandangan kabur, Silau, Perubahan daya lihat warna)

$$
\begin{aligned}
& =\operatorname{MIN}(0,8 ; 0,8 ; 0,6) * 0,80 \\
& =0,6 * 0,80 \\
& =0,48
\end{aligned}
$$

Fakta baru : Penyakit katarak Juvenil dengan nilai hipotesa $=0,48$

R5 = IF Penurunan ketajaman penglihatan AND Diplopia monokular AND Silau THEN Penyakit = Katarak Juvenil $(\mathrm{CF}=0,65)$ 
CF 5 = (Penurunan ketajaman penglihatan, Diplopia monocular, Silau)

$$
\begin{aligned}
& =\operatorname{MIN}(0,4 ; 0,6 ; 0,8) * 0,65 \\
& =0,4 * 0,65 \\
& =0,26
\end{aligned}
$$

Fakta baru : Penyakit katarak Juvenil dengan nilai hipotesa $=0,26$

R6 $=$ Tidak dieksekusi karena eviden TIDAK FAKTA

R7 = Tidak dieksekusi karena eviden TIDAK FAKTA

R8 = IF Radiasi sinar AND Luka memar area mata (benda tumpul) AND Zat kimia AND Silau THEN penyakit $=$ Katarak Traumatik $(\mathrm{CF}=0,70)$

CF 8 = (Radiasi sinar, Luka memar area mata (benda tumpul), Zat kimia, Silau)

$$
\begin{aligned}
& =\operatorname{MIN}(0,4 ; 0,8 ; 0,4 ; 0,8) * 0,70 \\
& =0,4 * 0,70 \\
& =0,28
\end{aligned}
$$

Fakta baru : Penyakit katarak Traumatik dengan nilai hipotesa $=0,28$

Karena R2 danR3 memiliki hipotesa yang sama maka R2 dan R3 digabung :

$\mathrm{CF} 2=0,3$

$\mathrm{CF} 3=0,32$

$\mathrm{CF}$ gabungan $1(\mathrm{CF} 2, \mathrm{CF} 3)=\mathrm{CF} 2+\mathrm{CF} 3 *(1-\mathrm{CF} 2)$

$=0,3+0,32 *(1-0,3)$

$=0,3+0,32 * 0,7$

$=0.434$

CF gabung R2 dan R3 $=0.434$

Karena R4 dan $\mathbf{R 5}$ memiliki hipotesa yang sama maka R4 dan $\mathbf{R 5}$ digabung.

CF $4=0,48$

$\mathrm{CF} 5=0,26$

$\mathrm{CF}$ gabungan1 $(\mathrm{CF} 4, \mathrm{CF} 5)=\mathrm{CF} 4+\mathrm{CF} 5 *(1-\mathrm{CF} 4)$

$=0,48+0,26 *(1-0,48)$

$=0,48+0,26 * 0,52$

$=0.3848$

CF gabung R4 dan R5 = 0.3848

Jadi $\boldsymbol{C F}$ gabungan $=$ Kongenital $=0,434=43.4 \%$

$\boldsymbol{C F}$ gabungan $=\boldsymbol{J}$ uvenil $=0,3848=38.48 \%$

$$
\boldsymbol{C F}=\text { Traumatik }=0.28=28 \%
$$

Jadi penyakit katarak yang dimiliki oleh user adalah Katarak Kongenital dengan Nilai kepastian (Certainty Factor $)=43.4 \%$.

\section{KESIMPULAN}

Sistem Pakar dapat digunakan sebagai alternatif di dalam melakukan diagnosa penyakit katarak dengan memasukkan nilai - nilai kepastian certainty factor terhadap gejala yang dirasakan oleh pengguna. Nilai tersebut merupakan nilai numeric yang telah diubah menjadi nilai linguistik sehingga dapat dipahami oleh pengguna pada umumnya.

Sistem pakar yang dihasilkan dapat menyimpulkan dalam bentuk persentase kemungkinan penyakit katarak yang diderita, serta memberikan solusi terhadap penyakit yang diderita oleh seorang pengguna.

\section{SARAN}

Peneliti menyadari masih banyak kekurangan di dalam melakukan penelitian ini. Salah satu yang harus diperhatikan adalah penggunaan platform berbasis web yang belum ramah terhadap teknologi mobile (Smartphone), sehingga dapat mengurangi minat dari pengguna untuk menggunakan sistem pakar ini. Untuk pengembangan berikutnya diharapkan sistem memiliki kemampuan multiplatform sehingga penggunaan sistem pakar dapat lebih dioptimalkan.

\section{DAFTAR PUSTAKA}

Agus, F., Wulandari, H. E. and Astuti, I. F. 2018. Expert System With Certainty Factor For Early Diagnosis Of Red Chili Peppers Diseases, Journal of Applied Intelligent System, 2(2), pp. 52-66. doi: 10.33633/jais.v2i2.1455.

Anwar, K. dkk.. 2016. Kalkulasi Bantuan Korban Bencana Alam Menggunakan Sistem Pakar ( Help Victims Of Natural Disasters Calculation Using Expert System ), Juita, IV, pp. 17-21.

Arifin, M., Slamin, S. and Retnani, W. E. Y. 2017. Penerapan Metode Certainty Factor Untuk Sistem Pakar Diagnosis Hama Dan Penyakit Pada Tanaman Tembakau, Berkala Sainstek, 5(1), p. 21. doi: 10.19184/bst.v5i1.5370.

Atmojo, S. and Utami, R. 2017. Web Sistem Pakar Pendiagnosa Penyakit Anak Umum dan HFMD menggunakan Certainty Factor, Jurnal Ilmiah Edutic, 3(2), pp. 83-90.

Wulandari, F., \& Yuliandri, I. 2014. Diagnosa Gangguan Gizi Menggunakan Metode Certainty Factor, Jurnal Sains, Teknologi dan Industri, 11(2), pp. 305-313.

Giarratano, J. C. dan Riley, G. D. 2005. Expert Systems Principles and Programming Fourth Edition, Boston, Massachusetts: Thomson Course Technology, pp. 167-173.

Irawan, G. M., Saerang, J. and Tongku, Y. 2015. Katarak Pada Anak Di Poliklinik Mata Blu Prof. Dr. R. D. Kandou Manado Periode Januari 2011 - Desember 2013, Jurnal e-Clinic, 3(April), pp. 2013-2016.

Kusrini, K. 2006. Sistem Pakar Teori dan Aplikasi.

Mevung, F. I. $d k k$. . 2017. Diagnosis Penyakit Kejiwaan Menggunakan Metode Certainty Factor, Prosiding Seminar Ilmu Komputer dan Teknologi Informasi, 2(1), pp. 374-380.

Mitra, N. N., Sovia, R. and Permana, R. 2019. Sistem Pakar Mendiagnosis Penyakit Kulit Pada Kucing 
Jenis Persia Menggunakan Metode Certainty Factor Berbasis Web, in Seminar Nasional Teknologi Komputer \& Sains (SAINTEKS).

Reisa, R. 2014. Sistem Pakar Untuk Diagnosis Penyakit Mata, Sistem Informasi, 2(2), pp. 30-35.

Setyaputri, K. E. and Fadlil, A. 2018. Analisis Metode Certainty Factor pada Sistem Pakar Diagnosa Penyakit THT, Scientific Journal of Informatics (SJI) UNNES, 10(1), pp. 30-35.

Sutojo, T., mulyanto, E. and suhartono, V. 2011. Kecerdasan buatan. Andi Offset.

Vlahavas, I. 2008. Artificial intelligence for advanced problem solving techniques. IGI Global.

Wahyumi, I., Amra, A. A. and others (no date) Prevalensi katarak pada anak di RSUP H. Adam Malik Medan tahun 2012, Majalah Kedokteran Nusantara The Journal Of Medical School, 46(1). 